\title{
PENGARUH RUTE SINTESIS TERHADAP KEEFEKTIFAN PENGIKATAN GUGUS PDETA PADA SINTESIS Fe $\mathrm{O}_{4} @ S i \mathrm{O}_{2} @ P D E T A$
}

\author{
Susanto $^{1^{*}}$ dan Ricka Prasdiantika ${ }^{1}$ \\ ${ }^{1}$ Fakultas Teknik Universitas Pandanaran Semarang \\ Submisi:08-06-2018; Revisi: 16-08-2018; Diterima: 16-08-2018
}

\begin{abstract}
Synthesis of $\mathrm{Fe}_{3} \mathrm{O}_{4} @ \mathrm{SiO}$, modified with propyldiethylene-triamine ( $\left.\mathrm{Fe}_{3} \mathrm{O}_{4} @ \mathrm{SiO}_{2} @ P D E T A\right)$ with variation of synthesis routes has been investigated. Research was begun with synthesis of $\mathrm{Fe}_{3} \mathrm{O}_{4}$ using dispersion agent of trisodium citrate at coprecipitation system through stirring with ultrasonic wave. Magnetite coating with propyldiethylenetriamine modified silica was carried out through sol-gel process with two different mixing sequences of raw materials (two synthesis routes) with main materials of $\mathrm{Fe}_{3} \mathrm{O}_{4}$ synthesized, $\mathrm{N}$-[3-(Trimethoxysilyl)propyl]diethylenetriamine (TMSPDETA) and $\mathrm{Na}_{2} \mathrm{SiO}_{3}$. The products were characterized by fourier transform infrared (FTIR) spectrophotometer and scanning electron microscope-energy dispersive X-ray (SEM-EDX). Results indicated that $\mathrm{Fe}_{3} \mathrm{O}_{4} @ \mathrm{SiO}_{2} @ P D E T A$ has been synthesized succesfully.Fe $\mathrm{O}_{4} @ \mathrm{SiO}_{2} @ P D E T A$ synthesized through route 1 (magnetite mixed with a mixture TMSPDETA and $\mathrm{Na}_{2} \mathrm{SiO}_{3}$ ) contains more propyldiethylenetriamine group than that of through route 2 (magnetite mixed with $\mathrm{Na}_{2} \mathrm{SiO}_{3}$ solution, then mixed with TMSPDETA).
\end{abstract}

Keywords: Binding effectiveness; Magnetite; Propyldiethylenetriamine; Silica modified; Synthesis routes.

\begin{abstract}
ABSTRAK
Sintesis silika termodifikasi propildietilentriamin yang dilapiskan pada magnetit $\left(\mathrm{Fe}_{3} \mathrm{O}_{4} @ \mathrm{SiO}_{2} @ \mathrm{PDETA}\right)$ dilakukan dengan variasi rute sintesis. Penelitian diawali dengan sintesis $\mathrm{Fe}_{3} \mathrm{O}_{4}$ yang menggunakan natrium sitrat sebagai agen pendispersi magnetit melalui pengadukan dengan gelombang ultrasonik. Pelapisan magnetit dengan silika termodifikasi propildietilentriamin dilakukan melalui metode solgel dengan dua perbedaan urutan pencampuran bahan utama (rute sintesis) dengan bahan utama $\mathrm{Fe}_{3} \mathrm{O}_{4}, \mathrm{~N}$-[3-(Trimetoksisilil)propil]dietilentriamina (TMSPDETA) dan $\mathrm{Na}_{2} \mathrm{SiO}_{3}$. Produk hasil sintesis dikarakterisasi dengan fourier transform infrared (FTIR) spectrophotometer dan scanning electron microscopeenergy dispersive X-ray (SEM-EDX). Hasil mengindikasikan bahwa $\mathrm{Fe}_{3} \mathrm{O}_{4} @ \mathrm{SiO}_{2} @$ PDETA telah berhasil disintesis. $\mathrm{Fe}_{3} \mathrm{O}_{4} @ \mathrm{SiO}_{2} @$ PDETA hasil sintesis dengan rute sintesis 1 (magnetit ditambahkan dengan campuran larutan $\mathrm{Na}_{2} \mathrm{SiO}_{3}$ dan TMSPDETA) memiliki lebih banyak gugus propildietilentriamin daripada sintesis dengan rute sintesis 2 (magnetit ditambahkan dengan larutan $\mathrm{Na}_{2} \mathrm{SiO}_{3^{\prime}}$, kemudian ditambah dengan TMSPDETA).
\end{abstract}

Kata Kunci: Keefektifan pengikatan; Magnetit; Propildietilentriamina; Rute sintesis; Silika termodifikasi.

\footnotetext{
${ }^{*}$ Corresponding author: susanto@unpand.ac.id

Copyright (C) 2018 THE AUTHOR(S). This article is distributed under a Creative Commons Attribution-Share Alike 4.0 International license.
} 


\section{PENGANTAR}

Material hibrida banyak diteliti karena memiliki sifat yang unik. Silika gel dapat digunakan sebagai matriks anorganik pada material hibrida anorganik-organik karena memiliki stabilitas mekanik dan termal yang baik, luas permukaan yang besar, dan permukaannya dapat dimodifikasi secara kimia (Liu dkk., 2013).

Silika gel termodifikasi sudah banyak disintesis sebagai adsorben tergantung pada donor atom aktif seperti $\mathrm{O}, \mathrm{S}$, dan $\mathrm{N}$ pada senyawa organik yang digunakan untuk modifikasi (Sales dan Airoldi, 2003; Mahmoud dkk., 2004; Roldan dkk., 2005). Material hibrida berupa material hibrida anorganik-organik memiliki potensi untuk digunakan sebagai adsorben pada proses adsorpsi (Chiu dkk., 2009). Adsorben yang termodifikasi senyawa organik bergugus propildietilentriamina dapat digunakan untuk menghilangkan ion logam berat (Lin dkk., 2011).

Adsorpsi adalah proses dimana satu atau lebih komponen adsorbat ditarik dan berikatan pada permukaan padatan adsorben ketika terjadi interaksi (Benavante, 2008). Adsorpsi merupakan teknik pemisahan yang menjanjikan untuk pemisahan logam berat karena menggunakan peralatan yang sederhana, biaya murah, mudah dioperasikan, lebih efisien pada konsentrasi ion logam yang rendah, ramah lingkungan, dapat dilakukan pada rentang $\mathrm{pH}$ dan temperatur yang luas, serta adsorbennya dapat diregenerasi (Ramesh dkk., 2008; Tabakci dan Yilmaz, 2008; Sigh dan Tiwari, 1999; Liu dkk., 2013; Fujiwara dkk., 2007; Nguyen dkk., 2010; Lo dkk., 2012; Moussavi and Talebi, 2012).

Akan tetapi, ada kesulitan saat pemisahan adsorben dari larutannya ketika adsorpsi dilakukan pada sistem batch. Oleh karena itu perlu digunakan partikel magnetik seperti magnetit $\left(\mathrm{Fe}_{3} \mathrm{O}_{4}\right)$ pada adsorben, karena magnetit bersifat paramagnetik sehingga adsorben dapat dipisahkan dari larutan menggunakan magnet eksternal (Zhang dkk., 2013). Sintesis magnetit dari Fe(II) dan Fe(III) dengan larutan amonia dengan pencucian menggunakan pelarut aseton air memiliki disperse partikel yang baik (Susanto dkk., 2016a).

Pelapisan silika gel pada magnetit secara langsung menyebabkan magnetit membentuk agregat setelah dilapisi silika (Wang dkk., 2001; Aliev dkk., 1999). Natrium sitrat dapat menghasilkan dispersi magnetit menjadi lebih baik pada saat proses pelapisan dengan silica (Farimani dkk., 2013).

Ada beberapa teknik sintesis adsorben magnetit terlapis silika $\left(\mathrm{Fe}_{3} \mathrm{O}_{4} @ \mathrm{SiO}_{2}\right)$ yang termodifikasi gugus aktif. Material hibrida organik-anorganik $\mathrm{Fe}_{3} \mathrm{O}_{4} @ \mathrm{SiO}_{2}$ yang termodifikasi gugus aktif dapat disintesis dengan cara larutan $\mathrm{Na}_{2} \mathrm{SiO}_{3}$ dan senyawa organik yang memiliki gugus fungsi aktif dicampur terlebih dahulu, kemudian ditambahkan pada magnetit yang telah diasamkan (Syukur, 2014). Cara sintesis yang lain untuk $\mathrm{Fe}_{3} \mathrm{O}_{4} @ \mathrm{SiO}_{2}$ yang termodifikasi gugus aktif yaitu dengan cara magnetit diasamkan terlebih dahulu, kemudian ditambah larutan $\mathrm{Na}_{2} \mathrm{SiO}_{3}$, setelah itu campuran ditambah senyawa organik yang memiliki gugus fungsi aktif (Mulyati, 2014). Kedua cara sintesis tersebut berbeda dalam urutan pencampuran (rute sintesis) yang menggunakan bahan-bahan: $\mathrm{Fe}_{3} \mathrm{O}_{4^{\prime}} \mathrm{Na}_{2} \mathrm{SiO}_{3^{\prime}}$ dan senyawa organik yang memiliki gugus fungsi aktif.

Pada penelitian ini disintesis material hibrida organik-anorganik yaitu magnetit terlapis silika yang termodifikasi gugus propildietilen-triamina $\left(\mathrm{Fe}_{3} \mathrm{O}_{4} @ \mathrm{SiO}_{2} @ \mathrm{PDETA}\right)$. Tujuan penelitian ini adalah mempelajari pengaruh urutan pencampuran bahan (rute sintesis) yang terdiri dari senyawa organik bergugus triamin dari reagen silan $\mathrm{N}$-[3(Trimetoksisilil)propil]dietilentri-amin] (TMSPDETA), $\mathrm{Na}_{2} \mathrm{SiO}_{3^{\prime}}$, dan $\mathrm{Fe}_{3} \mathrm{O}_{4}$ pada sintesis $\mathrm{Fe}_{3} \mathrm{O}_{4} @ \mathrm{SiO}_{2} @$ PDETA terhadap keefektifan pengikatan gugus PDETA dalam memperoleh rendemen dengan jumlah PDETA yang optimum. Manfaat dari penelitian ini adalah memberikan informasi rute sintesis yang efektif dalam pengikatan gugus PDETA untuk memperoleh rendemen dengan jumlah PDETA yang optimum pada sintesis $\mathrm{Fe}_{3} \mathrm{O}_{4} @ \mathrm{SiO}_{2} @$ PDETA dengan bahan utama TMSPDETA, $\mathrm{Na}_{2} \mathrm{SiO}_{3}$, dan $\mathrm{Fe}_{3} \mathrm{O}_{4}$. 


\section{Metode}

Magnetit yang dipergunakan pada penelitian ini telah dibuat sebelumnya yaitu berasal dari $\mathrm{Fe}_{3} \mathrm{O}_{4} @$ sitrat yang merupakan magnetit terdispersi natrium sitrat (Susanto dkk., 2016 ). Pembuatan $\mathrm{Fe}_{3} \mathrm{O}_{4} @ \mathrm{SiO}_{2} @ P D E T A$ menggunakan $\mathrm{Na}_{2} \mathrm{SiO}_{3}$ (Merck), $\mathrm{Fe}_{3} \mathrm{O}_{4} @$ sitrat, TMSPDETA (Aldrich), dan $\mathrm{HCl} 37 \%$ (Merck).

Peralatan yang digunakan pada penelitian ini meliputi alat preparasi dan peralatan analisis. Alat preparasi terdiri dari gelas ukur berbagai ukuran, labu ukur berbagai ukuran, gelas Beaker dengan berbagai ukuran, kertas $\mathrm{pH}$ universal, lumpang dan mortar porselen, Ultrasonic Branson 3210 (48 kHz, 220 Volt), oven (Fischer Scientific), neraca analitik (Metter AE 160), magnet eksternal (Niobium), dan shaker (VRN-200).

Alat analisis terdiri dari spektrtrofotometer Fourier Transform Infrared (FTIR, Shimadzu Prestige 21) untuk identifikasi gugus fungsional $\mathrm{Fe}_{3} \mathrm{O}_{4} @ \mathrm{SiO}_{2} @$ PDETA hasil sintesis dan Scanning Electron Microscope-Energy Dispersive X-ray (SEM-EDX, JEOL JED-2300) untuk analisis kadar C; N; dan Si pada material $\mathrm{Fe}_{3} \mathrm{O}_{4} @ \mathrm{SiO}_{2} @$ PDETA hasil sintesis.

Langkah kerja dalam penelitian ini terdiri dari variasi rute sintesis. Pada sintesis $\mathrm{Fe}_{3} \mathrm{O}_{4} @$ $\mathrm{SiO}_{2} @$ PDETA dengan rute sintesis 1 , seberat 0,5 $\mathrm{g} \mathrm{Fe}_{3} \mathrm{O}_{4}$ diasamkan dengan $1 \mathrm{~mL} \mathrm{HCl} 1 \mathrm{M}$ dan disonikasi 10 menit. Sebanyak $3 \mathrm{~mL}$ natrium silikat, 2,4 mL akuades, dan 1,8 mL TMSPDETA disonikasi selama 10 menit. Kemudian kedua larutan dicampur dan disonikasi selama 10 menit. Kemudian larutan ditetesi dengan $\mathrm{HCl}$ $1 \mathrm{M}$ sampai terbentuk gel lalu dipertahankan pada $\mathrm{pH} 7$ (netral), setelah itu disonikasi selama 30 menit. Larutan didiamkan selama 24 jam dan dicuci dengan akuades. Residu dipisahkan dengan magnet eksternal dan dikeringkan pada suhu $80^{\circ} \mathrm{C}$. Setelah kering, digerus dan dipisahkan dengan silika yang tidak terlapis pada magnet dengan menggunakan magnet eksternal, selanjutnya dikarakterisasi dengan spektrofotometer FTIR dan SEM-EDX.

Pada sintesis $\mathrm{Fe}_{3} \mathrm{O}_{4} @ \mathrm{SiO}_{2} @$ PDETA dengan rute sintesis 2, seberat $0,5 \mathrm{~g} \mathrm{Fe}_{3} \mathrm{O}_{4}$ diasamkan dengan $1 \mathrm{~mL} \mathrm{HCl} 1 \mathrm{M}$ dan disonikasi 10 menit. Sebanyak $3 \mathrm{~mL}$ natrium silikat dan $2,4 \mathrm{~mL}$ akuades ditambahkan, lalu campuran disonikasi selama 10 menit. Sebanyak $1,8 \mathrm{~mL}$ TMSPDETA ditambahkan, lalu campuran disonikasi selama 10 menit. Langkah selanjutnya sama dengan sintesis dengan rute sintesis 1 .

\section{HASIL DAN PEMBAHASAN}

Sintesis dengan rute sintesis yang memungkinkan terjadinya interaksi yang lebih efektif antara ion silikat dan TMSPDETA akan menyebabkan semakin banyak TMSPDETA yang bereaksi dengan ion silikat. Material $\mathrm{Fe}_{3} \mathrm{O}_{4} @ \mathrm{SiO}_{2} @$ PDETA hasil sintesis diidentifikasi keberhasilan sintesisnya dengan FTIR. Analisis keberhasilan sintesis $\mathrm{Fe}_{3} \mathrm{O}_{4} @ \mathrm{SiO}_{2} @$ PDETA diidentifikasi berdasarkan terbentuknya puncakpuncak karakteristik serapan FT-IR dari ikatan $\mathrm{C}-\mathrm{H}, \mathrm{C}-\mathrm{N}, \mathrm{Fe}-\mathrm{O}-\mathrm{Si}$, dan Si-O-Si serta gugus fungsional -OH dan - $\mathrm{NH}$ dari $\mathrm{Fe}_{3} \mathrm{O}_{4} @ \mathrm{SiO}_{2} @$ PDETA yang terbentuk. Hasil karakterisasi FTIR $\mathrm{Fe}_{3} \mathrm{O}_{4} @ \mathrm{SiO}_{2} @$ PDETA dengan variasi rute sintesis (urutan pencampuran bahan: $\mathrm{Fe}_{3} \mathrm{O}_{4^{\prime}}$ $\mathrm{Na}_{2} \mathrm{SiO}_{3^{\prime}}$ dan TMSPDETA) ditunjukkan pada Gambar 1.

Gambar 1.

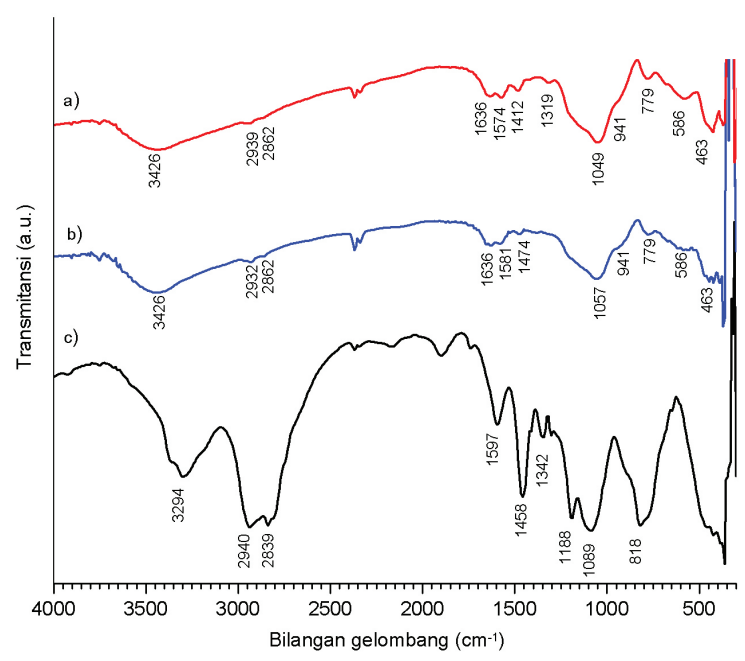

Spektra inframerah a) $\mathrm{Fe}_{3} \mathrm{O}_{4} @ \mathrm{SiO}_{2} @ \mathrm{PDETA}$ hasil sintesis dengan rute sintesis 1, b) $\mathrm{Fe}_{3} \mathrm{O}_{4} @ \mathrm{SiO}_{2} @$ PDETA hasil sintesis dengan rute sintesis 2, dan c) TMSPDETA sebagai standar

Bilangan gelombang pada $463 \mathrm{~cm}^{-1}$ mengindikasikan adanya vibrasi ulur $\mathrm{Si}-\mathrm{O}-\mathrm{Fe}$ seperti yang dikemukakan Khosroshahi dan 
Ghazanfari (2010). Bilangan gelombang pada 586 $\mathrm{cm}^{-1}$ mengindikasikan adanya vibrasi ulur Fe-O magnetit seperti yang dikemukakan Voronkov (1996). Bilangan gelombang pada $779 \mathrm{~cm}^{-1}$ mengindikasikan adanya vibrasi ulur simetris Si-O-Si seperti yang dikemukakan Jacintho dkk. (2009). Bilangan gelombang pada $818 \mathrm{~cm}^{-1}$ mengindikasikan adanya vibrasi ulur simetris $\mathrm{Si}$ O-C seperti yang dikemukakan Haw dkk. (2011).

Bilangan gelombang pada $941 \mathrm{~cm}^{-1}$ mengindikasikan adanya vibrasi ulur $\mathrm{Si}-\mathrm{OH}$ seperti yang dikemukakan Nuryono dkk. (2014). Bilangan gelombang pada 1049-1057 $\mathrm{cm}^{-1}$ mengindikasikan adanya vibrasi ulur asimetris $\mathrm{Si}-\mathrm{O}-\mathrm{Si}$ seperti yang dikemukakan Susanto dkk. (2016 b).

Bilangan gelombang pada $1089 \mathrm{~cm}^{-1}$ mengindikasikan adanya vibrasi ulur asimetris Si-O-C seperti yang dikemukakan Haw dkk. (2011). Bilangan gelombang pada 1319 $\mathrm{cm}^{-1}$ mengindikasikan adanya vibrasi C-N seperti yang dikemukakan Pavia dkk. (2001). Bilangan gelombang pada 1412-1474 $\mathrm{cm}^{-1}$ mengindikasikan adanya vibrasi tekuk $\mathrm{CH}_{2}$ - seperti yang dikemukakan Pavia dkk. (2001). Bilangan gelombang pada 1574-1594 $\mathrm{cm}^{-1}$ mengindikasikan adanya vibrasi tekuk $\mathrm{N}-\mathrm{H}$ seperti yang dikemukakan Pavia dkk. (2001). Bilangan gelombang pada $1636 \mathrm{~cm}^{-1}$ mengindikasikan adanya vibrasi ulur $\mathrm{O}-\mathrm{H}$ dari $\mathrm{Si}-\mathrm{OH}$, permukaan magnetit yang berinteraksi dengan air seperti yang dikemukakan Nuryono dkk. (2014) dan Farimani dkk. (2013).

Bilangan gelombang pada $2839-2862 \mathrm{~cm}^{-1}$ mengindikasikan adanya vibrasi ulur simetris C-H seperti yang dikemukakan Vorkonov (1996). Bilangan gelombang pada 2932-2940 $\mathrm{cm}^{-1}$ mengindikasikan adanya vibrasi ulur asimetris C-H seperti yang dikemukakan Vorkonov (1996). Bilangan gelombang pada $3294 \mathrm{~cm}^{-1}$ mengindikasikan adanya vibrasi ulur N-H primer seperti yang dikemukakan Pavia dkk. (2001). Bilangan gelombang pada $3426 \mathrm{~cm}^{-1}$ mengindikasikan adanya vibrasi ulur N-H primer seperti yang dikemukakan Vorkonov (1996) serta vibrasi ulur O-H dari $\mathrm{Si}-\mathrm{OH}$, permukaan magnetit yang berinteraksi dengan air seperti yang dikemukakan Nuryono dkk. (2014) dan Farimani dkk. (2013).
Berdasarkan spektra inframerah pada Gambar 5, terbentuknya ikatan C-H, C-N, Fe$\mathrm{O}-\mathrm{Si}$ dan $\mathrm{Si}-\mathrm{O}-\mathrm{Si}$ serta gugus fungsional $-\mathrm{OH}$ dan NH mengindikasikan bahwa $\mathrm{Fe}_{3} \mathrm{O}_{4} @ \mathrm{SiO}_{2} @$ PDETA berhasil disintesis melalui proses solgel disintesis dengan rute sintesis 1 dan 2 .

Pada $\mathrm{Fe}_{3} \mathrm{O}_{4} @ \mathrm{SiO}_{2} @$ PDETA hasil sintesis dengan rute sintesis 1 diperoleh puncak karakteristik ikatan pada gugus PDETA terutama pada puncak bilangan gelombang $1412 \mathrm{~cm}^{-1}$ yang mengindikasikan adanya vibrasi tekuk $-\mathrm{CH}_{2}$ - dan $1574 \mathrm{~cm}^{-1}$ yang menunjukkan adanya vibrasi tekuk N-H dan mucul puncak $1319 \mathrm{~cm}^{-1}$ yang mengindikasikan adanya vibrasi C-N seperti yang dikemukakan Pavia dkk. (2001) dari gugus PDETA.

Pada sintesis dengan rute sintesis 2 diperoleh puncak karakteristik ikatan pada gugus PDETA terutama pada puncak bilangan gelombang $1474 \mathrm{~cm}^{-1}$ yang mengindikasikan adanya vibrasi tekuk $-\mathrm{CH}_{2}-$ dan $1581 \mathrm{~cm}^{-1}$ yang menunjukkan adanya vibrasi tekuk N-H seperti yang dikemukakan Pavia dkk. (2001) dan tidak mucul puncak karakteristik vibrasi C-N dari gugus PDETA pada $1319 \mathrm{~cm}^{-1}$.

Pada hasil sintesis $\mathrm{Fe}_{3} \mathrm{O}_{4} @ \mathrm{SiO}_{2} @$ PDETA dengan rute sintesis 1 diperoleh puncakpuncak bilangan gelombang dari gugus PDETA tersebut lebih tajam dan memiliki nilai yang lebih kecil dibandingkan pada sintesis dengan rute sintesis 2 . Hal tersebut mengindikasikan bahwa pada sintesis $\mathrm{Fe}_{3} \mathrm{O}_{4} @ \mathrm{SiO}_{2} @$ PDETA dengan rute sintesis 1 memiliki gugus PDETA yang lebih banyak daripada sintesis dengan rute sintesis 2. Dengan demikian mengindikasikan bahwa pada sintesis $\mathrm{Fe}_{3} \mathrm{O}_{4} @ \mathrm{SiO}_{2} @$ PDETA dengan rute sintesis 1 memiliki lebih banyak TMSPDETA yang bereaksi dengan ion silikat.

Untuk meyakinkan hal tersebut maka dilakukan analisis EDX untuk mengetahui kadar C, N, dan Si pada $\mathrm{Fe}_{3} \mathrm{O}_{4} @ \mathrm{SiO}_{2} @$ PDETA hasil sintesis dengan variasi urutan pencampuran bahan di BPPT Universitas Gadjah Mada. Hasil karakterisasi SEM-EDX pada $\mathrm{Fe}_{3} \mathrm{O}_{4} @ \mathrm{SiO}_{2} @$ PDETA hasil sintesis dengan variasi urutan pencampuran bahan ditunjukan pada Tabel 1. 
Tabel 1. Kadar C, N dan Si pada $\mathrm{Fe}_{3} \mathrm{O}_{4} @$ $\mathrm{SiO}_{2} @ P D E T A$ dengan rute sintesis 1 dan 2

\begin{tabular}{lcccc}
\hline \multirow{2}{*}{$\begin{array}{c}\mathrm{Fe}_{3} \mathrm{O}_{4} @ \mathrm{SiO}_{2} @ P D E T A \\
\text { dengan rute sintesis }\end{array}$} & $\mathbf{C}$ & $\mathbf{N}$ & $\mathrm{Si}$ \\
\cline { 3 - 5 } & & 20,84 & 15,89 & 15,82 \\
\hline 2 & 18,26 & 11,11 & 19,07 \\
\hline
\end{tabular}

Berdasarkan Tabel 1, sintesis $\mathrm{Fe}_{3} \mathrm{O}_{4} @ \mathrm{SiO}_{2} @$ PDETA dengan rute sintesis 1 menghasilkan $\mathrm{Fe}_{3} \mathrm{O}_{4} @ \mathrm{SiO}_{2} @ \mathrm{PDETA}$ dengan kadar $\mathrm{C}$ dan $\mathrm{N}$ lebih banyak dibandingkan pada intesis $\mathrm{Fe}_{3} \mathrm{O}_{4} @ \mathrm{SiO}_{2} @ \mathrm{PDETA}$ dengan rute sintesis 2 . Hal ini mengindikasikan bahwa pada sintesis dengan rute sintesis 1 menghasilkan $\mathrm{Fe}_{3} \mathrm{O}_{4} @$ $\mathrm{SiO}_{2} @$ PDETA dengan gugus PDETA yang lebih banyak daripada sintesis dengan rute sintesis 2. Dengan demikian mengindikasikan bahwa pada rute sintesis 1, TMSPDETA bereaksi lebih optimal dengan ion silikat yang belum terikat dengan magnetit. Hal ini didukung dengan hasil citra SEM pada Gambar 2.

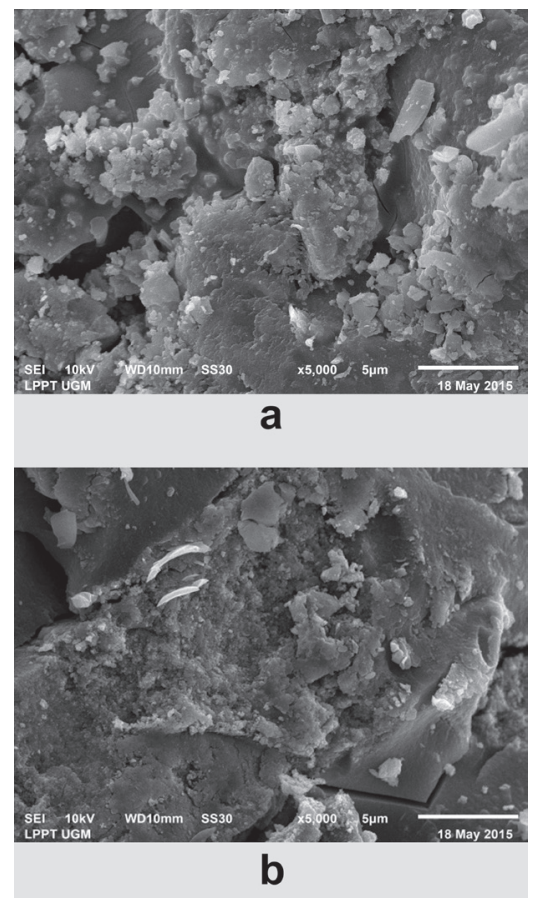

Gambar 2.

Citra SEM perbesaran $5000 \times$ (a) $\mathrm{Fe}_{3} \mathrm{O}_{4} @ \mathrm{SiO}_{2} @$ PDETA hasil sintesis dengan rute sintesis 1 , (b) $\mathrm{Fe}_{3} \mathrm{O}_{4} @ \mathrm{SiO}_{2} @$ PDETA hasil sintesis dengan rute sintesis 2

Gambar 2 menunjukkan hasil citra SEM per 5000 kali pada $\mathrm{Fe}_{3} \mathrm{O}_{4} @ S_{2} \mathrm{O}_{2} @$ PDETA hasil sintesis dengan rute sintesis 1 dan (b) $\mathrm{Fe}_{3} \mathrm{O}_{4} @$ $\mathrm{SiO}_{2} @$ PDETA hasil sintesis dengan $\mathrm{r} \mathrm{u} \mathrm{t}$ e sintesis 2. Warna hitam menunjukan bagian magnetit dan bagian abu-abu menunjukan bagian silika termodifikasi gugus PDETA.

Berdasarkan data spektra inframerah dan data SEM-EDX, $\mathrm{Fe}_{3} \mathrm{O}_{4} @ \mathrm{SiO}_{2} @$ PDETA yang disintesis dengan variasi urutan pencampuran bahan kemudian diprediksi proses pembentukan ikatannya. Proses pembentukan hipotetik pada sintesis $\mathrm{Fe}_{3} \mathrm{O}_{4} @ \mathrm{SiO}_{2} @$ PDETA yang telah dilakukan yaitu reaksi pengasaman $\mathrm{Fe}_{3} \mathrm{O}_{4} @$ sitrat dan reaksi pelapisan dengan silika termodifikasi propilendietilentriamina pada magnetit tersebut. Hal ini juga dapat dibuktikan dari hasil karakterisasi inframerah $\mathrm{Fe}_{3} \mathrm{O}_{4} @$ sitrat dan $\mathrm{Fe}_{3} \mathrm{O}_{4} @ \mathrm{SiO}_{2}$ yang ditunjukkan pada Gambar 3.

Pada suasana asam, $\mathrm{Fe}_{3} \mathrm{O}_{4} @$ sitrat mengalami reaksi dengan ion silikat dari $\mathrm{Na}_{2} \mathrm{SiO}_{3}$. $\mathrm{Fe}_{3} \mathrm{O}_{4} @$ sitrat mengalami pertukaran ligan dengan senyawa berbasis silika $\left(\mathrm{Na}_{2} \mathrm{SiO}_{3}\right)$, selajutnya ligan berbasis silika tersebut mengalami kondensasi melapisi permukaan magnetit seperti yang dikemukakan Pavia dkk. (2001).

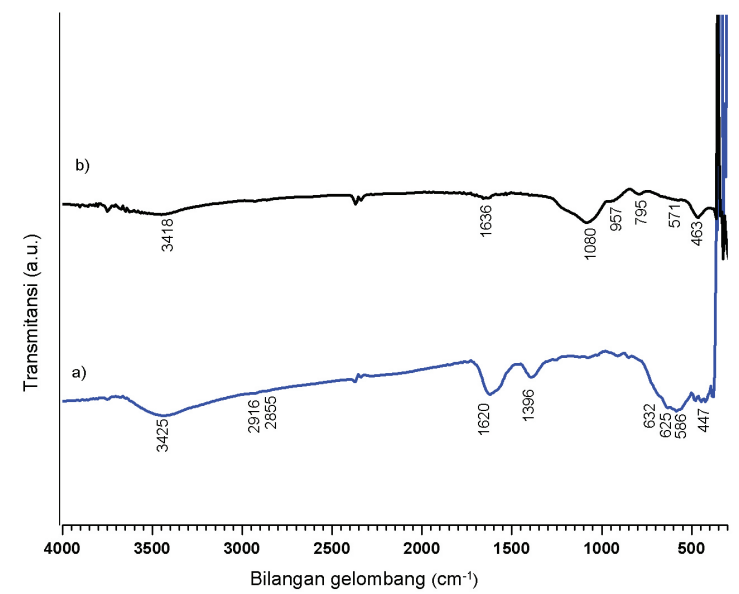

Gambar 3.

Spektra inframerah $\mathrm{Fe}_{3} \mathrm{O}_{4} @$ sitrat: a) sebelum dan b) sesudah ditambah $\mathrm{Na}_{2} \mathrm{SiO}_{3}$

Berdasarkan Gambar 3, pada $\mathrm{Fe}_{3} \mathrm{O}_{4} @$ sitrat yang ditambah dengan $\mathrm{Na}_{2} \mathrm{SiO}_{3}$ memiliki puncak karakteristik dari gugus silika dan tidak memiliki puncak karakteristik dari 
gugus sitrat. Berdasarkan gelombang 2, puncak karakteristik dari gugus silika terdapat pada bilangan gelombang $(1080,957,795$, dan 463) $\mathrm{cm}^{-1}$ Bilangan gelombang pada 1080 $\mathrm{cm}^{-1}$ mengindikasikan adanya vibrasi ulur asimetris $\mathrm{Si}-\mathrm{O}-\mathrm{Si}$ seperti yang dikemukakan Khosroshahi dan Ghazanfari (2010). Bilangan gelombang pada $957 \mathrm{~cm}^{-1}$ mengindikasikan adanya vibrasi ulur Si-OH seperti yang dikemukakan Nuryono dkk. (2014). Bilangan gelombang pada $463 \mathrm{~cm}^{-1}$ mengindikasikan adanya vibrasi ulur $\mathrm{Si-O}-\mathrm{Fe}$ seperti yang dikemukakan Khosroshahi dan Ghazanfari (2010).

Berdasarkan gambar 3, puncak karakteristik dari gugus sitrat terdapat pada bilangan gelombang $(632,1620,1396,2916$, dan 2885) $\mathrm{cm}^{-1}$. Bilangan gelombang pada $632 \mathrm{~cm}^{-1}$ mengindikasikan adanya interaksi Fe dengan -COO- sitrat seperti yang dikemukakan Hong dkk. (2008). Bilangan gelombang pada (1620 dan 1396) $\mathrm{cm}^{-1}$ mengindikasikan adanya vibrasi adanya vibrasi ulur asimetri dan simetri dari gugus -COO sitrat seperti yang dikemukakan Farimani dkk. (2013) dan Susanto $\left(2016^{\mathrm{b}}\right)$. Bilangan gelombang pada $2916 \mathrm{~cm}^{-1}$ dan $2885 \mathrm{~cm}^{-1}$ mengindikasikan adanya vibrasi ulur asimetri dan simetri C-H seperti yang dikemukakan Vorkonov (1996).

Pada sintesis $\mathrm{Fe}_{3} \mathrm{O}_{4} @ \mathrm{SiO}_{2} @$ PDETA, magnetit berinteraksi langsung dengan silika termodifikasi propildietilentriamin. Senyawa berbasis silika berupa silika termodifikasi TMSPDETA tersebut memiliki gugus silanol (Si-OH). Gugus silanol merupakan gugus aktif yang dapat berikatan dengan gugus $\mathrm{Fe}-\mathrm{OH}$ dari permukaan magnetit yang telah diasamkan seperti yang dikemukakan Nuryono dkk. (2014). Sumber silika pada penelitian ini adalah $\mathrm{Na}_{2} \mathrm{SiO}_{3}$. Pada saat sintesis $\mathrm{Fe}_{3} \mathrm{O}_{4} @ \mathrm{SiO}_{2} @$ PDETA, $\mathrm{Na}_{2} \mathrm{SiO}_{3}$ yang digunakan ditambah dengan air. Dalam media air, larutan natrium silikat terdisosiasi menjadi ion-ion seperti yang dikemukakan Coradin dan Lopez (2003) seperti pada persamaan reaksi berikut:

$$
\mathrm{Na}_{2} \mathrm{SiO}_{3}(\mathrm{aq}) \rightarrow 2 \mathrm{Na}^{+}(\mathrm{aq})+\mathrm{SiO}_{3}^{2-}(\mathrm{aq})
$$

Pada proses pelapisan magnetit dengan silika termodifikasi gugus, secara umum terdiri dari 3 bagian yaitu reaksi pembentukan ikatan $\mathrm{Si}-\mathrm{O}-\mathrm{Si}$, reaksi pembentukan $\mathrm{Fe}-\mathrm{O}-\mathrm{Si}$, dan reaksi kondensasi seperti yang dikemukakan Nuryono dkk. (2014). Pada penelitian ini, proses pembentukan hipotetik untuk $\mathrm{Fe}_{3} \mathrm{O}_{4} @$ $\mathrm{SiO}_{2} @$ PDETA pada sintesis dengan variasi rute sintesis secara umum terdiri dari pembentukan hipotetik ikatan Si-O-Si yang ditunjukkan pada Gambar 5, pembentukan hipotetik ikatan FeO-Si yang ditunjukkan pada Gambar 6, dan reaksi hipotetik kondensasi yang ditunjukkan pada Gambar 7.

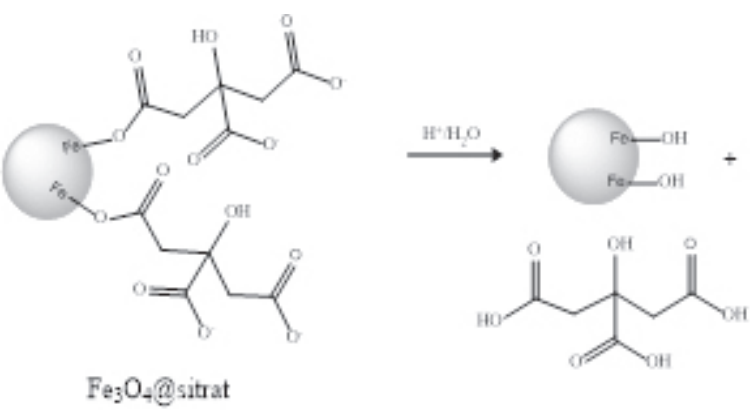

Gambar 4. Reaksi hipotetik pengasaman pada $\mathrm{Fe}_{3} \mathrm{O}_{4} @$ sitrat
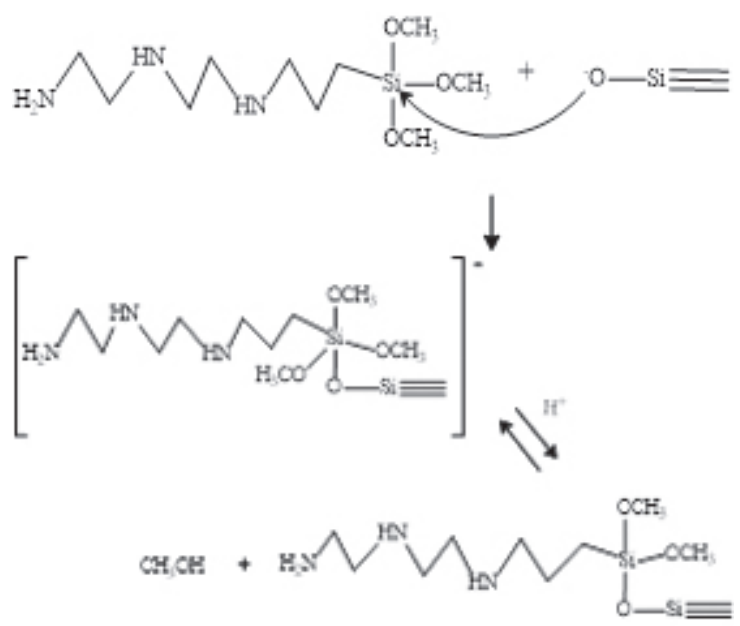

Gambar 5.

Pembentukan hipotetik ikatan Si-O-Si 


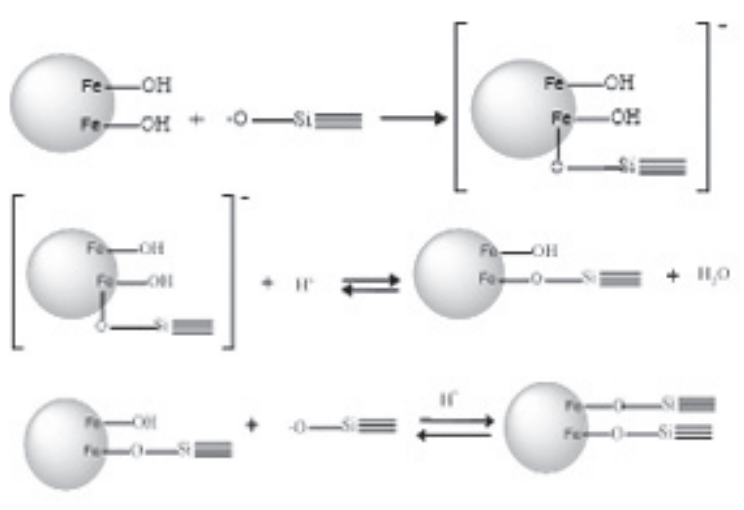

Gambar 6.

Pembentukan hipotetik ikatan Fe-O-Si

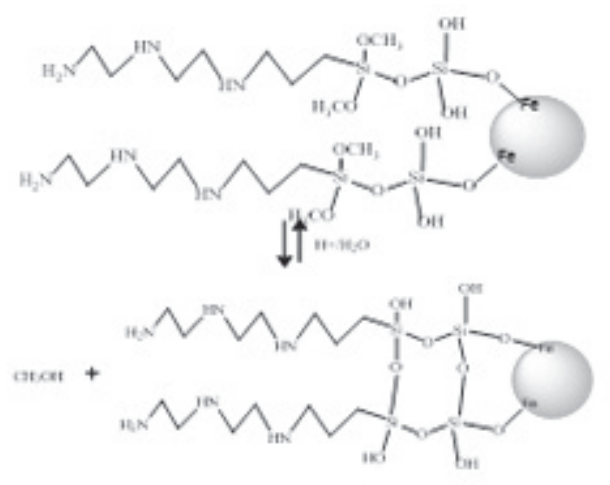

Gambar 7.

Reaksi hipotetik kondensasi

Pada proses pembentukan hipotetik $\mathrm{Fe}_{3} \mathrm{O}_{4} @ \mathrm{SiO}_{2} @ \mathrm{PDETA}$ untuk sintesis dengan rute sintesis 1, ion silikat direaksikan terlebih dahulu dengan TMSPDETA dengan membentuk jembatan Si-O-Si, kemudian direaksikan dengan $\mathrm{Fe}_{3} \mathrm{O}_{4}$ yang sudah diasamkan dengan membentuk Fe-O-Si, kemudian terjadi reaksi kondensasi. Pada proses pembentukan hipotetik $\mathrm{Fe}_{3} \mathrm{O}_{4} @ \mathrm{SiO}_{2} @$ PDETA untuk sintesis dengan rute sintesis 2 , ion silikat direaksikan terlebih dahulu dengan $\mathrm{Fe}_{3} \mathrm{O}_{4} @$ sitrat yang sudah diasamkan dengan membentuk Fe-O$\mathrm{Si}$, kemudian direaksikan dengan TMSPDETA dengan membentuk jembatan Si-O-Si, kemudian terjadi reaksi kondensasi.

Pada $\mathrm{Fe}_{3} \mathrm{O}_{4} @ \mathrm{SiO}_{2} @$ PDETA hasil sintesis dengan rute sintesis 2, TMSPDETA yang bereaksi jumlahnya lebih sedikit dibandingkan pada sintesis dengan rute sintesis 1 . Hal ini disebabkan karena waktu interaksi antara
TMSPDETA dengan ion silikat cenderung lebih sebentar pada sintesis dengan rute sintesis 2 , sehingga hanya terjadi sedikit tumbukan efektif antara TMSPDETA dengan ion silikat. Selain itu pada pada sintesis dengan rute sintesis 2, ion silikat sudah berikatan dengan magnetit terlebih dahulu sebagaimana ditunjukkan pada Gambar 8 (b), sehingga gerakan molekulnya kurang bebas ketika berinteraksi dengan TMSPDETA dibandingkan pada sintesis dengan rute sintesis 1 yang ion silikatnya belum berikatan dengan magnetit ketika berinteraksi dengan TMSPDETA sebagaimana yang ditunjukkan pada Gambar 8(a).

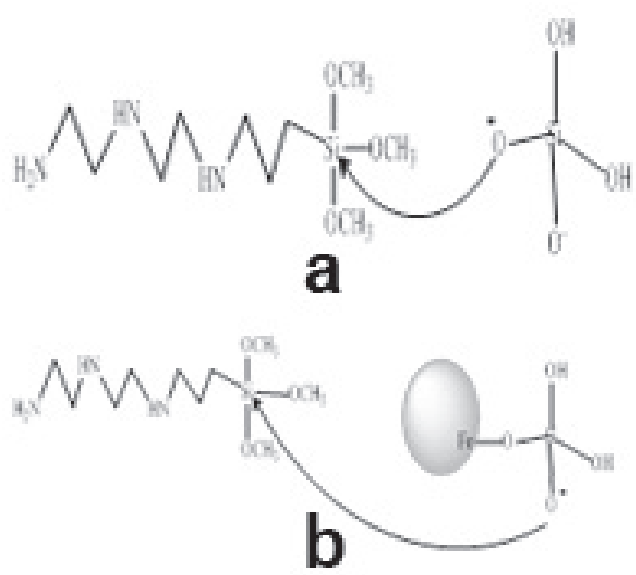

Gambar 8.

Interaksi hipotetik antara ion silikat dan TMSPDETA pada sintesis dengan: (a) rute sintesis 1 dan (b) rute sintesis 2

Berdasarkan spektra inframerah, data SEM-EDX, dan proses pembentukan hipotetik pada sintesis $\mathrm{Fe}_{3} \mathrm{O}_{4} @ \mathrm{SiO}_{2} @ \mathrm{PDETA}$ dengan variasi urutan pencampuran bahan (rute sintesis), maka sintesis dengan rute sintesis 1 lebih efektif untuk sintesis $\mathrm{Fe}_{3} \mathrm{O}_{4} @ \mathrm{SiO}_{2} @$ PDETA. Sintesis $\mathrm{Fe}_{3} \mathrm{O}_{4} @ \mathrm{SiO}_{2} @$ PDETA dengan rute sintesis 1 dengan cara menambahkan campuran larutan $\mathrm{Na}_{2} \mathrm{SiO}_{3}$ dan TMSPDETA ke dalam magnetit yang telah diasamkan menghasilkan rendemen dengan gugus PDETA yang lebih banyak dan puncak karakteristik dari gugus PDETA yang lebih tajam daripada sintesis $\mathrm{Fe}_{3} \mathrm{O}_{4} @ \mathrm{SiO}_{2} @$ PDETA dengan rute sintesis 2. 


\section{SIMPULAN}

Berdasarkan data spektra inframerah dan SEM-EDX, sintesis dengan rute sintesis 1 yaitu magnetit yang sudah diasamkan, ditambahkan dengan campuran larutan natrium silikat dan reagen silan $\mathrm{N}$-[3-(Tri-metoksisilil) propil] dietilentriamin] (TMSPDETA) memiliki pengikatan gugus propildietilentriamin (PDETA) yang lebih efektif yang menghasilkan $\mathrm{Fe}_{3} \mathrm{O}_{4} @$ $\mathrm{SiO}_{2} @$ PDETA dengan gugus PDETA pada yang lebih banyak dibandingkan sintesis dengan rute sintesis 2 (magnetit yang diasamkan, ditambahkan dengan lautan natrium silikat, kemudian ditambah TMSPDETA).

\section{UCAPAN TERIMA KASIH}

Terima kasih kepada Prof. Dr. Nuryono, M.S. atas bantuan bahan penelitian yang diberikan.

\section{DAFTAR PUSTAKA}

Aliev, F. G., M. A. Correa-Duarte, A. Mamedov, J. W. Ostrander, M. Giersig, L.M. Lix-Marzan, and N.A. Kotov. 1999. Layer-By-Layer Assembly of Core-Shell Magnetite Nanoparticles: Effect of Silica Coating on Interparticle Interactions and Magnetic Properties. Advanced Materials 11(12): 1006-1010.

Benavente, M. 2008. Adsorption of Metallic Ions onto Chitosan: Equilibrium and Kinetic Studies, Thesis, Department of Chemical Engineering and Technology. Royal Institute of Technology. Sweden.

Chiu, H., C. Liu, S. Chen, and S. Suen. 2009. Adsorptive Removal of Anionic Dye by Inorganic-Organic Hybrid AnionExchange Membranes. Journal of Membrane Science 337(1-2):282-290.

Coradin, T. dan P.J. Lopez. 2003. Biogenic Silica Patterning: Simple Chemistry or Substle Biology. ChemBioChem 4(4): 251-259.

Farimani, N.S., N.G. Roknabadi, and A. Kazemi. 2013. Study of Structural and Magnetic Properties of Super- paramagnetic $\mathrm{Fe}_{3} \mathrm{O}_{4} / \mathrm{SiO}_{2}$ Core-Shell Nanocomposites Synthe-sized with Hydrophilic Citrate-Modified $\mathrm{Fe}_{3} \mathrm{O}_{4}$ Seeds via A Sol-Gel Approach. Physica E 53: 207-216.

Fujiwara, K., A. Ramesh, T. Maki, H. Hasegawa, K. Ueda.2007. Adsorption of platinum (IV), palladium (II) and gold (III) from aqueous solutions onto l-lysine modified crosslinked chitosan resin. Journal of Hazardous Materials. 146 (1-2): 39-50.

Haw, C.Y., Chia, C.H., Zakaria, S., Mohamed, and F., Radiman, S., Teh, C.H., Khiew, P.S., Chiu, W.S., and Huang, N.M., 2011, Morphological Studies of Randomized Dispersion Magnetite Nanoclusters Coated with Silica, Ceramics International 37(2): 451-464.

Hong, R.Y., J.H. Li, H.Z. Li, J. Ding, Y. Zheng, and D.G. Wei. 2008. Synthesis of $\mathrm{Fe}_{3} \mathrm{O}_{4}$ Nanoparticles without Inert Gas Protection Used as Precursors of Magnetic Fluids. Journal of Magnetism and Magnetic Materials 320(9): 1605-1614.

Jacintho, G.V.M., A.G. Brolo, P. Corio, P.A.Z. Suarez, and J.C. Rubim. 2009. Structural Investigation of $\mathrm{MFe}_{2} \mathrm{O}_{4}$ $(\mathrm{M}=\mathrm{Fe}, \mathrm{Co})$ Magnetic Fluids. Journal of Physical Chemistry C 113(18): 76847691.

Khosroshahi, M.E., and L. Ghazanfari. 2010. Prepara-tion and Characterization of Silica-Coated Iron-Oxide Bionanoparticles under $\mathrm{N}_{2}$ Gas. Physica $E$ 42(6): 1824-1829.

Lin, Y., H. Chen, K. Lin, B. Chen, and C. Chiou. 2011. Application of Magnetic Particles Modified with Amino Groups to Adsorb Copper Ions in Aqueous Solution. Journal of Environmental Sciences 23: 44-50.

Liu, W., P. Yin, X. Liu, X. Dong, J. Zhang, and Q. Xu. 2013. Thermo Dynamics, Kinetics, and Isotherms Studies For gold(III) Adsorption Using Silica Functionalized by Diethylenetriamine 
Methy-lene Phosphonic Acid. Chemical Engineering Research and Design 91(12): 2748-2758.

Lo, S.F., Wang, S.Y., Tsai, M.J., Lin, L.D. 2012. Adsorption capacity and removal efficiency of heavy metal ions by Moso and Ma bamboo activated carbons. Chemical Engineering Research and Design 90(9): 1397-1406.

Mahmoud, M.E., M.M. El-Essawi, S.A. Kholeif and E.M.I. Fathalla. 2004. Aspects of Surface Modification, Structure characterization, Thermal Stability and Metal Selectivity properties of Silica Gel PhasesImmobilized-Amine Derivati-ves. Analytica Chimica Acta 525(1): 123132. Moussavi, G. and S. Talebi. 2012. Comparing the efficacy of a novel waste-based adsorbent with PAC for the simultaneous removal of chromium (VI) and cyanide from electroplating wastewater. Chemical Engineering Research and Design 90(7): 960-966.

Mulyati, E. 2014. Pelapisan Magnetit dengan Hibrida Merkapto-Silika untuk Adsorpsi Selektif Au(III) dari Sistem Multilogam $\mathrm{Au}(\mathrm{III}) / \mathrm{Cu}(\mathrm{II}) / \mathrm{Ni}(\mathrm{II})$. Tesis. Departemen Kimia FMIPA UGM. Yogyakarta.

Nguyen, N.V., J. Lee, S. Kim, M.K. Jha, K. Chung, J. Jeong. 2010. Adsorption of gold(III) from waste rinse water of semiconductor manufacturing industries using Amberlite XAD7HP resin. Gold Bulletin, 43(3): 200208.

Nuryono, N., N.M. Rosiati, B. Rusdiarso, S.C.W. Wibawa Sakti, and S. Tanaka. 2014. Coating of Magnetite with Mercapto Modified Rice Hull Ash Silica in a One-Pot Process. SpringerPlus 3(515):1-12.

Pavia, D.L., G.M. Lampman, and J.R. Vyvyan. 2001. Introduction to Spectroscopy, $4^{\text {th }}$
Ed. Western Washington University. Washington.

Roldan, P.S., I.L. Alcântara, C.C.F. Padilha, and P.M. Padilha. 2005. Determination of Copper, Iron, Nickel And Zinc in Gasoline by FAAS after Sorption and Preconcen-tration on Silica Modifiedwith 2-Amino-tiazole Groups, Fuel, 84(2): 305-309.

Sales, J.A.A., and C. Airoldi. 2003. Epoxide Silylant Agent ethylenediamine Reaction Product Anchored on Silicagel-Thermodynamics of Cation-Nitrogen Interaction At solid/Liquid Interface. Journal of NonCrystalline Solids 330(1-3):142-149.

Susanto, S., R. Prasdiantika, T.C.M. Bolle. 2016. Sintesis Nanomaterial MagnetitSitrat dan Pengujian Aplikasinya sebagai Adsorben Emas(III). Jurnal Teknosains 6(2):124-129.

Susanto, S., Prasdiantika, R., dan Bolle, T.C. 2016. Pengaruh Pelarut Terhadap Dispersi Partikel $\mathrm{Fe}_{3} \mathrm{O}_{4} @$ Sitrat. Jurnal Sains Materi Indonesia, 17(4): 153-159.

Syukur, M. 2014. Sintesis $\mathrm{Fe} 3 \mathrm{O} 4 / \mathrm{SiO} 2$ Termodifikasi (N-(2-Aminoetil)-3Aminopropil) untuk Adsorpsi-Desorpsi Anionik $\left[\mathrm{AuCl}_{4}\right]$. Tesis. Departemen Kimia FMIPA UGM. Yogyakarta.

Voronkov, M.G. 1966. Silatranes: IntraComplex Heterocyclic Compounds of Pentacoordinated Silicon. Pure and Applied Chemistry 13(1-2): 35-60.

Wang, H., H. Nakamura, Y. Yao, H. Maeda, and E. Abe. 2001. Effect of Solvents on the Preparation of Silica-Coated Magnetic Particles, Chemistry Letters 30(11): 1168-1169.

Zhang, Y., Q. Xu, S. Zhang, J. Liu, J. Zhou, H. Xu, H. Xiao, and J. Li. 2013. Preparation of Thiol-Modified $\mathrm{Fe}_{3} \mathrm{O}_{4} @ \mathrm{SiO}_{2}$ Nanoparticles and Their Application for Gold Recovery From Dilute Solution. Separation and Purification Technology 116: 391-397. 